\title{
Georgian Hero of the Soviet Era Against the Universe: Science Fiction as a Nation's Coping Mechanism
}

\author{
KETEVAN CHARTOLANI \\ Free University of Tbilisi
}

\section{INTRODUCTION}

When in 1934 the First Congress of Soviet Writers canonized socialist realism as the only permitted and acceptable literary mode of the Soviet Union, the event marked a decisive shift in the development of Georgian culture, in general, and its literary tradition, in particular. From this day on, a writer's only mission was to become a mouthpiece of the Communist Party. Officially, this meant complying with two directives: 1) a socialist realist text had to faithfully depict the contemporary reality 2) and this -reality was to be positive. These two demands were mutually exclusive in the years of forced collectivization that brought severe outbreaks of famine, followed by the series of the political repressions that were unprecedented in their scope and brutality. To resolve the contradiction, writers, instead of mirroring the grim reality, began creating new, jollier ones. They started using various tricks and tropes so that their fictional universes could resemble the soviet life as convincingly as possible. ${ }^{1}$ One such trick was to adopt a science fictional premise and set the novel in the future where all the hardships of the real present no longer existed, as was promised by the Party.

The fact that the emergence of the Georgian science fiction coincided with the establishment of the socialist realist principles, is not accidental. ${ }^{2}$ While as a rule an interest towards the genre ignites in societies that have undergone the industrial revolution, Georgia of the 1930s could hardly be called a technologically developed country. Georgian science fiction was born out of a necessity to serve the needs of the totalitarian system, which tried to transform its citizens into a new type of a human bomo sovieticus. Thus, those Georgian writers who chose to try their strength in this genre were mostly promulgators of the Soviet ideology. However, science fiction, being a politically charged genre in its

\footnotetext{
${ }^{1}$ For the peculiar characteristics of Soviet socialist realism, see Katerina Clark, The Soviet Novel (Chicago: The University of Chicago Press, 1981), Boris Groys, The Total Art of Stalinism (Princeton, New Jersey: Princeton University Press, 1992). 2 The first Georgian science fictional novel was published four years prior to the official adoption of socialist realism, however, the Party's changing attitude towards the acceptable style of writing became more and more apparent already in the beginning of the thirties, when Maxim Gorky, one of the creators of the socialist realist guidelines, besides Joseph Stalin and Andrey Zhdanov, actively reappeared on the Soviet Union's literary scene, after spending almost ten years abroad.
} 
core, always entails an aspect of criticism, making it immune towards the total submission to the oppressive system. ${ }^{3}$

In this article I will analyze the Soviet Georgian science fiction within the postcolonial framework and will argue that, while complying with the principles of socialist realism, these novels offer a unique perspective on the issue of preserving Georgian national identity within the totalitarian socialist empire. To do so, I will focus on three tropes that expose the peculiar center-periphery relations between Russia and Georgia that can be found in the science fictional texts published between the years of 1930 and 1991: 1) equating Georgia to the Soviet center by depicting the Georgian hero as a pillar of the future communist society; 2) equating Georgia to the Soviet center by transforming Russia's political rivals into the Georgia's enemies as the West becomes the inferior Other; 3) showing resentment towards the political status quo by criticizing the colonialist worldview and politics. The aim of the article is to show the dual nature of the Georgian Soviet science fiction, as it simultaneously served and opposed the oppressive system, thus creating a unique postcolonial narrative.

\section{Colonial Roots of SCIENCE Fiction}

From its very inception, science fiction was concerned with such topics as crossing new borders, discovering virgin lands, or meeting alien cultures, which connected the genre with the processes of colonialism. With technological innovations brought by the industrial revolution, western colonial expansion entered the new, most energetic phase in the beginning of the XIX century. Besides its practical use when it came to fast travel and subjugation of indigenous people by force, the technological progress played another, equally important role in the process of colonization: it served as the foundation of the colonizers' worldview and reinforced the conviction that the West was one possessing the cultural advantage. Thus, Europeans were deemed to be more developed than people living in the peripheries, justifying the aggressive politics of the western states. Such was the historical context that gave birth to the genre of science fiction. ${ }^{4}$

\footnotetext{
3 According to Darko Suvin, formal characteristics of science fictional texts force the reader to critically evaluate their reality and, by comparing fictional world to the empirical one, not only see the imperfections of the reality, but also identify that these imperfections are not absolute norms and can be changed in accordance with the specific needs. See Darko Suvin, Positions and Presuppositions in Science Fiction (Montreal: Macmillan Press, 1988).

${ }^{4}$ For more detailed exploration of the interconnectedness of the genre with the colonialism, see John Rieder, Colonialism and the Emergence of Science Fiction (Middletown, Connecticut: Wesleyan University Press, 2008), Patricia Kerslake, Science
} 
Indeed, the cultures where science fiction developed as a coherent genre, belonged to the countries with imperialist ambitions. It was only natural that the science fiction of these empires including Tsarist Russia - brooded over the concepts that were the backbone of the colonialist ideology. The cultural or racial Other in these texts was replaced by an alien from far-away star systems, eastern or southern lands were replaced by various exoticized planets and their conquest became the central politico-ethical dilemma that drove the narrative's central conflict. Science fiction played a role of an intermediary between political elites with the imperialist agenda and civilians. In contrast to dry political directives, the main advantage of science fiction as a promoter of imperialism was the fact that these texts could romanticize the process of discovering new lands, thus downplaying the practical side of conquests and ignoring the economic benefits and brutal nature of the whole enterprise.

However, it would have been wrong to argue that all of early science fiction blindly served the needs of the imperialist ideology. It is true that the vast majority of the texts written during the second half of the XIX and the first decades of the XX centuries justified the militaristic expansion of the western empires. However, holding strictly colonial point of view was never the defining, essential characteristic of the genre. ${ }^{5}$ In other words, science fiction has always had a special interest towards the workings of the empire, but this interest itself contained various opposing positions. Istvan Csicsery-Ronay, Jr. explains this ambiguous relationship between science fiction and the empire in this manner: 'Sf artists construct stories about why this Empire is desired, how it is achieved, how it is managed, how it corrupts (for corrupt it must), how it declines and falls, how it deals with competing claims to imperial sovereignty, or how it is resisted ${ }^{6}{ }^{6}$ Thus, we can look at science fiction as a cultural tool that helps readers evaluate those fundamental changes that were brought by the era of colonialism.

Technological, cultural or ethical superiority in relations to alien civilizations, creation and mastery of new lands and communication with indigenous people are the defining tropes of the Soviet Georgian science fiction too. The analyses of some of these passages shows the attempts of creating a new Georgian national identity, the construction of which became necessary after the country lost its independence to the Soviet state in 1921. Treating Soviet Union as an empire, with Russia being its center and other Soviet Socialist Republics - its colonies, gives us useful methodological tools for explaining specific nuances when it comes to the complex relations between Russia and Georgia in

Fiction and Empire (Liverpool University Press: Liverpool, 2007), Jessica Langer, Postcolonialism and Science Fiction (London: Palgrave Macmillan, 2011).

${ }^{5}$ For example, in the 1897 H.G. Wells classic, 'The War of the Worlds', the author humanizes people living in colonies by making England technologically inferior to its Martian conquerors.

${ }^{6}$ Istvan Csicsery-Ronay, Jr., 'Science Fiction and Empire', Science Fiction Studies 30.2 (2003), p. 236. 
the XX century. ${ }^{7}$ According to Edward Said, the literary texts created within a colonial context can be seen as co-creators of the imperialist politics. ${ }^{8}$ Therefore, the research done on the Georgian Soviet science fiction crosses the boundaries of the literary studies and can enrich the postcolonial literature in general. However, it must also be noted that the Saidian center-periphery binarity focuses more on the nature of the center, rather than on its peripheries, while we are interested in the perspective of the periphery and its struggles for self-preservation.

While analyzing Japanese and Native Canadian science fiction, Jessica Langer focuses on the narratives, where the writers of the colonized people construct national identities independent from the colonizer's gaze 'by projecting themselves into the future on their own terms'. ${ }^{9}$ Unfortunately, the same cannot be said in relations to the Soviet science fiction, as the future of the Soviet Union was monopolized by the Party in accordance to the Marxist model of historical materialism. ${ }^{10}$ This future was strictly defined and it was inhabited by those people only, who possessed the pre-defined worldview and character traits. Any author that would have attempted to arbitrary change any aspect of this vision, would have fallen under the scrutiny of the state-controlled censorship machine. Hence, the sub-genre of the socialist realism that dealt with imagining the humankind's future, had to comply to the well-established Party directives. The Georgian science fiction published during the Soviet Union rarely steps beyond the borders set by the state. However, with some unusual combinations of officially permitted tropes, we can find models of the future, where Georgia becomes the center of the utopian communist society, while Russia either is depicted as an equal cultural entity or disappears from the picture completely.

Patricia Kerslake describes the process of the creation of a periphery by a center as a onesided action, where the Other plays the role of a passive object. The periphery, thus, is defined by such traits that center sees no qualitative value in and ascribes them to the Other. ${ }^{11}$ But when a periphery is created by not a center but by a subjugated colony, those 'half-imagined, half-known' monsters that populate this imagined space obtain surprising value; the process of periphery-creation becomes the act of looking in the mirror and owning to the fact of your own oppression. ${ }^{12}$ On the

\footnotetext{
7 Works that analyze the Soviet Union as an empire include Vladislav M. Zubok, (A Failed Empire) The Soviet Union in the Cold War from Stalin To Gorbachev (Chapel Hill: The University of North Carolina Press, 2009), Francine Hirsch, Empire of Nations (Ithaca: Cornell University Press, 2005).

${ }^{8}$ Edward W. Said, Culture and Imperialism (New York: Vintage Books, 1994), p. xiv.

${ }^{9}$ Langer, Postcolonialism and Science Fiction, p. 45.

10 According to the view held by the Soviet officials and reinforced by the socialist realism principles, the future was determined, the Communism was inevitable, thus the party could boast the successes of the future that had yet to come.

${ }^{11}$ Kerslake, Science Fiction and Empire, p. 9.

12 Edward W. Said, Orientalism (Vintage Books, A Division of Random House Inc., New York, 1979), p. 63.
} 
other hand, when you are defined as the Other by the center, constructing your own identity independent from the existing dichotomy becomes a means for self-preservation. Thus, when you are not in possession of your own peripheral Other, the only thing you can do is to imagine one. And who creates most believable inexistent spaces, and who inhabits those spaces with simultaneously most phantasmagoric and realistic, most scary and charming, most alien and at the same time familiar creatures than the writer of science fiction?

\section{Georgian Hero in THE Center of THE UNiverse}

The Georgian Soviet science fiction played by the rules of socialist realism. Therefore, when it came to the creation of a unique national identity, the authors molded it not in binary opposition to the Russian identity, but by mimicking it. According to Homi Bhabha, when a periphery presents itself as a center, the hybrid identity is created. People with such identities are carriers of the double consciousness - they exist at the merge of two cultures and mask their dependency on the center by a number of conscious or unconscious coping mechanisms. This practice is called mimicry and in the postcolonial literature it is defined as the process of appropriating habits, attitudes, language and culture of the oppressor. ${ }^{13}$ However, Bhabha makes it clear that the aim of the mimicry is not to completely replace the old identity with the new one. The aim, instead, is camouflage, that is - one only pretends to share the same identity with a conqueror. Homi Bhabha sees in mimicry a great political power, as it, by playing the game of make-believe, has the ability to show the real intentions of the empire, which hides behind the mask of a benevolent master: 'It is from this area between mimicry and mockery, where the reforming, civilizing mission is threatened by the displacing gaze of its disciplinary double[...]'. ${ }^{14}$

The desire to mimic the center can only develop in a person who either sympathizes with the colonizer or seeks some kind of benefit from it. Such a complex attitude, which simultaneously contains the desires for assimilation and preservation of the national identity, is defined by the term 'ambivalence'. The main source of the ambivalent attitude of Georgians towards the Soviet state is

\footnotetext{
${ }^{13}$ Homi K. Bhabha, The Location of Culture (New York: Routledge, 1994), pp. 102-123.
}

${ }^{14}$ Ibid., p. 86. 
connected with a figure of Joseph Stalin. The fact that the nationality of the most powerful leader of the Soviet Union was Georgian, fed and is still feeding the nationalist ambitions and pride of many Georgians. The Georgian lineage of Stalin was seen as the proof that, in contrast to other socialist republics in Caucasus or Asia, Georgia occupied the equal position with Russia when it came to the cultural and political potency and, thus, was equally developed. As Georgia could boast its unique, centuries-old cultural heritage and literary tradition, the desire to mimic Russia manifested itself in ascribing the political power and the level of independency Russia enjoyed, to Georgia. Therefore, it is not surprising that in Georgian science fiction the colonial mimicry is manifested in those heroes, who show the political will to act independently from Moscow's directives.

Such a hero always acts in the name of the technologically developed center and even in such far futures, where national states cease to exist, he stubbornly retains distinctively stereotypical Georgian traits and physiognomy. For example, in a short story called Tetri Usasruloba [The White Infinity], we see the future of the Earth where no national borders exist, while the science has developed so much that now only genetically modified people with perfect physical and mental traits are being born. ${ }^{15}$ Nevertheless, when describing the appearance of a protagonist, Alan Kolkhi, ${ }^{16}$ the author makes it clear that the natural perfection can only be found in Georgian genes and, thus, they need no artificial enhancement:

Exercised, broad-shouldered and quick on his feet, [Alan Kolkh] always felt the satisfaction derived from the perfect nature of his own body. His face was also handsome, even the great migration of humankind on the surface of the Earth could not erase the Georgian heritage in his being: he had slightly crooked, thin nose, undeterred hazel eyes gazing under the unibrow and dark auburn hair and beard. ${ }^{17}$

This is the anatomy of the Georgian hero, whose identity is the focus of this article, as we seek to identify the elements of the imagined realities that make the existence of such a figure possible. To do so, we must describe the center our hero represents and answer the following questions: Who is

\footnotetext{
${ }^{15}$ Elguja Merabishvili, 'Tetri Usasruloba' ['The While Infinity'] in Dakarguli Andromake [Lost Andromaque] (Tbilisi: Nakaduli, 1978), pp. 103-147.

${ }^{16}$ Kolkh, same as Colchis, is the name of the ancient Georgian kingdom.

${ }_{17}$ Merabishvili, 'Tetri Usasruloba', p. 105.
} 
his antagonist and where does he dwell? How does our hero find common language with alien creatures? Or how does he oppose them when the gap between the civilizations is too deep to overcome? Finding answers to these questions equals finding those specific characteristics of a new Georgian identity, the creation of which became necessary to preserve the national distinctiveness in a reality, where political sovereignty was absent.

In the Georgian science fiction this very identity can be found within the permitted boundaries set by the Party and it exists intertextually throughout the decades. In particular, the civilized center that the Georgian hero represents, is always communist in form; In relations to other civilizations, it is always ethically superior and quite often has the technological advantage as well. In culturally homogeneous society of the future, only the Georgian hero is able to preserve his national traits and this very unique characteristic makes him worthy of becoming the protagonist of the story. The honor, the personal virtues, the complexity of the inner world of the hero and basically any trait that puts him in an advantageous position in regards to his comrades and adversaries, are inevitably linked to the fact that he, first and foremost, is Georgian.

This is the reason why, whenever the Georgian hero leaves the Earth to complete his hero journey, the main thing that drives him is the hope of returning back to Georgia. Such peculiar motivation sets the hero apart from all other characters. Among this faceless, nationless mass of people, even the most clichéd and stereotypically Georgian trait that sets deep in the conscious of our hero, becomes the magical missing ingredient that helps him overcome all obstacles. For example, in another short story of the same author, Aias Mdrivi [A Bead of Aeaea], ${ }^{18}$ we meet the protagonist, Captain Vilen Meskhi ${ }^{19}$ in his spacecraft, suffering from the deadly disease called 'space nostalgia', as is his co-pilot with a distinctly foreign name - Adam Con. ${ }^{20}$ The thing these characters are nostalgic about determines the level of the resistance each of their bodies are capable of manifesting against the disease. Adam is tortured by the vision of his beloved, Lucia, strolling in the grain-field: 'Lucia's hair, tousled by the wind, shimmered like the harp strings. As she walked, her body swayed gently, her pretty, long fingers barely touching the shimmering harp strings, and she singed about the beauty of nectarines blossoming in April, about the first love....2.

\footnotetext{
18 Aeaea is a mythological name of the Kingdom of Colchis.

19 Vilen was a typical Soviet name, comprised of the first letters of Lenin's full name - Vladimir Ilich Lenin; Meskhi is a name of a Georgia's ethnographic subgroup, however, it is also a common Georgian last name.

${ }^{20}$ Elguja Merabishvili, 'Aias Mdzivi' ['A Bead of Aeaea'] in Dakarguli Andromake [Lost Andromaque] (Tbilisi: Nakaduli, 1978), pp. 174-202.

${ }^{21}$ Ibid., p. 178.
} 
Meanwhile, Vilen dreams about Tbilisi, the capital of Georgia. In his visions the city is personified, Tbilisi is his sweetheart, as is apparent from the similar poetic language the author uses to describe the hero's vision: 'sunny morning in Tbilisi, intrinsic ornaments on pavements created by shadows ... Elbakidze Downhill covered in dew, whispering girls on a bridge, abandoned, opened book on a parapet....22 And while longing for Lucia drives Adam to the edge of his life, as he falls in the agony of death, for Vilen Tbilisi becomes the stimulus to gather his strengths and fight death. Vilen not only survives, but finds the way to cure his comrade too. By the end of the story the author once again underlines the importance of the native land for the Georgian hero: While Adam stays behind on the planet where they encounter the utopian society, Vilen, who by now has found his one and true love on this planet, rejects the invitation and returns to the Earth.

Further into the cosmos the Georgian hero travels, vaster becomes the center he represents; Further in time we meet him, more persistently do nationalities and cultures of the Earth vanish. But even when Georgia, as a political entity, no longer exists, its culture is personified in the protagonist. In a universe of the XXV century, created by a Georgian science fiction writer and critic, Nugzar Apkhazava, we meet another Georgian explorer, captain Uta Phasia. ${ }^{23}$ In Uta's reality Georgia, as a geographical unit, no longer exists and the earth itself is the member of 'The Milky Way NR Association'. ${ }^{24}$ However, the Earth was granted the access to this economic-political association due to Georgia, the country that had spearheaded the planet's technological progress. The reader is informed that in the 80's of the XX century in a city of Sadaris located next to Tbilisi, the generation responsible for conquering the cosmos was raised. ${ }^{25}$ Graduates of the local Poladauri School were the first humans to establish the contact with otherworldly civilizations. However, Uta sees himself not as Georgian, but as a descendent of the Old Colchidian culture. This distinction emphasizes the apolitical nature of the hero's ethnocentricity.

Focusing on the cultural uniqueness of Georgia instead of his political sovereignty, was the acceptable border the Party set for the socialist realist writers. To step beyond this border meant taking a dangerous political stance that would have attracted the attention of the state censorship. The only instance when a Georgian science fiction writer dared to try the patience of Moscow can be found in

\footnotetext{
22 Ibid., p.176.

${ }^{23}$ Phasia is a shortened form of word 'Phasis' which is a name of an ancient proto-Georgian city located on the coast of the Black Sea that belonged to the Colchis kingdom).

${ }^{24}$ Nugzar Apkkazava, Mzis Despani anu Uta Phasias Kosmosuri Odisea [The Emissary of the Sun or the Space Odyssey of Uta Phasia] (Tbilisi: Nakaduli, 1980).

${ }^{25}$ Fictional city the name of which translates from Georgian as 'where is it'.
} 
a novel by Ivane Kipiani, Amoni Anu Atasi Tslis Shemdeg [Amoni or One Thousand Years After], published in 1935. In this text a Georgian scientist, Giorgi, is revived in a utopian future society a thousand years after his death. When he finds out that the communist ideal has finally come to fruition and there are no more nations or cultures left but one, the Amonian civilization, Giorgi undergoes a severe psychological trauma: 'Transformation of his country into a charming geographical location gave him no solace whatsoever, ${ }^{26}$ Giorgi recovers a bit after he finds out that the progenitors of Amonian civilization were none others than Georgians, as all other nations and cultures had naturally, peacefully and gradually assimilated themselves with the Georgian culture.

\section{WEST AS AN EXOTIC OTHER}

To fully describe the identity of the Georgian science fictional hero, we must also analyze his antagonist, as creating the Other is the essential part of self-identification. In western literary tradition, the science fictional Other - be it an inhabitant of a far-away planet, a robot created by a human, an artificial intelligent, a cyborg or other kind of a hybrid - as a rule represents the fictional prototype of a society's marginalized group: 'Traditionally, science fiction's aliens have been modeled on certain practical categories of otherness that fascinate the dominars of culture: children, women (and sometimes men), machines, marginalized peoples, animals, and "anomalous genders" '.27 The representation of such an alien may serve one of two opposing goals: 1) the reinforcement of the status quo by rendering their oppression as a norm; 2) or, conversely, the weakening of the status quo by showing the absurdity and cruelty of oppressive practices.

For the first type of science fiction 'the only good alien is a dead alien'. ${ }^{28}$ As for the second type of the science fiction, the alien is humanized by depicting those features that both We and the Others have in common. In both cases, however, the text is written from the point of view of the privileged. In other words, the narrator belongs to the Us category and their aim is to praise or critique the privileged center they happen to belong to. For an author of the Georgian science fiction to assume such a position is a luxury. In reality, the Georgian Soviet identity was politically dependent, peripheral Other. Therefore, in these texts the fantastical element enters not with the appearance of an actual

\footnotetext{
${ }^{26}$ Ivane Kipiani 'Amoni Anu Atasi Tslis Shemdeg [Amoni or One Thousand Years After]' in Kartuli Sabchota Romani [Georgian Soviet Novel] (Tbilisi: Merani, 1987), pp. 256-257.

${ }^{27}$ Istvan Csicsery-Ronay, Jr., The Seven Beauties of Science Fiction (Middletown, Connecticut: Wesleyan University Press, 2008), p. 200.

${ }^{28}$ Ursula K. Le Guin, The Language of the Night (New York: Harper Perennial, 1989), p. 94.
} 
alien or a hybrid, but the moment Georgia is rendered as the center of a communist civilization. This very moment defines the end of a naturalistic storytelling and the reader is asked to suspend their disbelief and step into a make-believe world. Thus, by analyzing the nature of the Georgian science fictional antagonist, we won't be able to inspect the Georgian Soviet identity as it actually was, but instead - as it was dreamed to be. Other in these texts serves not as the tool for the deconstruction of a real identity, but as the tool for the construction of the imagined one.

There are mainly two types of antagonists in the Georgian Soviet science fiction. The first is a traditionally science-fictional non-human (inhabitant of the alien planet, robot, cyborg, hybrid); the second one is a specifically soviet science fictional phenomenon as it embodies the westerner $-\mathrm{a}$ citizen of the USA or some west European country - seen from the prism of the Soviet propaganda. This prototypical anti-hero possesses intertextually repeated, bizarrely uniform characteristics. Dehumanization, and often even demonization, of the westerners in this genre in the Georgian literature starts from the 50s of the XX century, when the Cold War between the United States and the Soviet Union enters its tensest stage. While the degree of devotion towards the Soviet ideology changes from one text to the other throughout the 70 years of the existence of the Georgian Soviet Socialist Republic, the declared hatred towards the capitalist world remains unchangeably acute until the collapse of the Soviet Union.

This westerner, capable of endangering the bright future of a better half of the humankind, was everything that a Soviet citizen was not meant to be. In the Georgian Soviet science fiction, the westerner is simultaneously amoral and fanatically religious, grotesquely rich and always in search of new material possessions, cruelly evil and comically fool. He has an intertextually repeated physical traits: he is fat, he has narrow, devilish eyes and resembles some type of an esthetically unappealing wild animal - as a rule a seal, a pig, or a walrus. He is always surrounded with two artifacts: cigars and alcohol - mostly whisky. His environment is exoticized: he dwells in urban jungles where highways, stretched between monstrous skyscrapers, carry colorful beasts - cabriolets. Here, tribal rituals are replaced by the exchange of dollars - an act that is always described as something tasteless and even disgusting. This place has its specific sound - here 'one can hear the vulgar and fidgeting chords of a Jazz-band, accompanied by the pretentious and idiotic voice of a man'. ${ }^{29}$ These dazzling colors, these giddy heights, this deafening symphony grants the West the allure of a forbidden fruit and, paradoxically, marks it with an orientalist exoticism.

${ }^{29}$ Apolon Basilaia, Chveni Misamarti [Our Home-Address] (Tbilisi: Sablitgami, 1956), p. 45. 
Because a technologically developed savage is an oxymoron, at some point the west must be stripped off its scientific prowess. Hence, the West of the far future loses its capability to adapt to the environment and ceases to exist as a political and cultural unit capable of technological inventions. In some cases, it physically ceases to exist, in others, it is assimilated with the communist society and, in both instances, no longer poses any threat. However, assimilation, as a rule, is never complete, as the inferiority of the capitalist west is too intrinsic for a complete purification to take place. For example, on the Uta Phasia's XXV-century-earth, the states no longer exist, however a character with a German cultural identity, Herr Erich von Keller, is the only unsympathetic person among the Georgian and Russian heroes. He, described as having narrow eyes, colorless eyebrows and unnerving wet lips, shows an inappropriate indifference towards the tragic accident of a spacecraft on the Hidalgo Asteroid. Even before this accident, Uta is seemingly annoyed by his German colleague. His sentiments are shared by a Russian 'Chef Frau Lyudmila'. ${ }^{30}$ She, 'a lady with strips of grey hair' and 'slightly sad, big, blue eyes' is a complete antipode of the German and is adored by Uta, as he sees in her an incarnation of beauty and dignity. ${ }^{31}$

In this short story the negative representation of the West does not end with the unsympathetic depiction of Keller, as four astronauts killed in the accident turn out to be the last victims of its shameful capitalist past. The astronauts' lives are taken by the bullets shot on the surface of the asteroids four centuries ago. Uta, who investigates the accident, tells us how these bullets got stuck in the orbit of the asteroid: in 1993, the administration of an American Monopoly - 'VanadiumCompany' had hired a group of scientists and bandits. The group was ordered to abduct the starship in order to mine the various asteroids found in the Solar System. Their mission was to find a rare mineral - Vanadium. The group found the mineral in the strata of the Hidalgo Asteroid, but the greed got best of them and they started shooting, annihilating each other and leaving the deadly bullets in search of new victims, for "the seed of evil is sometimes as potent as the couch-grass'. ${ }^{32}$

In the passages discussed in this section, the West is dethroned from its historically assumed position in the center of the civilization. The imperialist gaze is turned against westerners and, as they are being judged through the prism of the Soviet propagandist machine, they become dehumanized. In this manner, the West is treated with the same courtesy it treated its colonies during the centuries of colonization. However, because this depiction of the West is not reinforced by the real conflict -

\footnotetext{
30 Apkkazava, Mzis Despani anu Uta Phasias Kosmosuri, p.106.

31 Ibid., p. 107.

32 Ibid., p. 122.
} 
Georgia has never suffered from the western European colonization - the tension becomes comical. When a non-existent conflict is translated into the language of science fiction, instead of disturbing the discriminative status quo, such narratives reinforce it; the aim of these passages is not to shame the West, but to please the real center - Moscow, to blindly follow its directives. Thus, the drama is turned into a farce.

\section{Postcolonial NarRatives}

The process of postcolonialism starts from the moment a territory becomes a colony of the empire, and continues way after its collapse. It is the process in which the colonized people are engaged to preserve their ethnic or national distinctiveness and, after gaining the independence, to construct or reconstruct the national identity independent from the former center. Postcolonialism, thus, almost always entails the critique of the imperialism and opposes the system of believe which is reinforced by the orientalist writings (fiction or non-fiction). As we have already seen, when it comes to the Georgian Soviet science fiction, the main coping mechanism against the colonization is mimicry. In the fantasy worlds constructed by Georgian science fiction writers, Georgia has never undergone military invasion from the Soviet state, as it represents the center with its own peripheries. Therefore, it is not surprising that the authors sometimes adopt the orientalist worldview and, in such rare cases, the imaginary Georgia resembles some western European country of the XVII-XIX centuries.

When a school-boy Gia travels back in time to the XVII century, and meets Daniel Defoe and his 'savages', the reader is invited into the classical orientalist novel of the Victorian era. ${ }^{33}$ Technological advantage, which is automatically translated into the ethical superiority, grants Gia the right to simultaneously dehumanize and enlighten the nameless island's indigenous people. The shaman of the cannibal tribe Gia is captured by, perfectly represents the typical orientalist 'savage', which John Reider describes as creatures with

the 'daemonic' quality, $[\ldots]$ as if they are possessed by a single quality that dictates their appearance, and directs all of their behavior in one narrow channel. Believability is the last quality one would expect or desire from such

\footnotetext{
${ }^{33}$ Tamaz Cheishvili, Siriusi Idumali Stumari [Sirius, a Mysterious Guest] (Tbilisi: Nakaduli, 1985).
} 
figures. Their comic and critical effectiveness arises from their hyperbolic display of the vice or folly that inhabits them $[\ldots]^{34}$

The shaman in a Cheishvili novel is a cookie-cutter version of such a caricature. While Gia is tied to a pole, he is forced to observe the primitive rituals the tribe-people perform around the fire: 'The shaman was performing the "Dance of Fire" and Gia wholeheartedly hated, loathed this terriblelooking man, who seemed to be the incarnation of the evil'. ${ }^{35}$ As soon as Gia frees himself with the help of a chief's daughter (who, of course falls in love with a mysterious, handsome white man, who in this case is, disturbingly, no older than fifteen), 'he rushed towards the center of the field and kicked the shaman from behind with his leg so hard that the man sprawled on the grass ${ }^{36}$

However, there are couple of instances, when the Georgian Soviet science fiction speaks from the position of a periphery and these passages represent the critique of the imperialist worldview. In a short story called Usasrulobidan [From Infinity], the highly developed civilization of the planet Uru receives strange signals from a part of the cosmos they believed was an uninhabited, desolate periphery of their galaxy. ${ }^{37}$ The protagonist, Era, is forced to abandon his mission, which was to travel in the center of the galaxy in search of a valuable source of energy. Instead, he is ordered to change the course and find the source of the signals. At first, Era finds his new order unacceptable, as for him 'to travel to the periphery means to go back in past'. ${ }^{38}$ But by the end of the story he learns to look at his universe from a changed perspective and to see the value of his new mission: 'Maybe for them [the creatures who sent the signals] it is us who are part of the universe we deem as a vacuum, a periphery. Oh, how everything changes the minute you start looking at the universe from a different angle'. ${ }^{39}$

The cornerstone of the imperialist ideology - the claim of being in possession of the universal truth - is criticized in another story, called Ormagi Shetsdoma [A Double-sided Mistake], as well. ${ }^{40}$ Gigantic inhabitants of a gigantic planet located in the center of an unknown galaxy are exploring the periphery of the Milky-way Galaxy for the first time. When the planet Earth appears on their radars, they immediately decide that it is desolate, as the intelligent life has no capability to develop on such a tiny

\footnotetext{
34 Rieder, Colonialism and the Emergence of Science Fiction, p. 72.

35 Tamaz Cheishvili, Siriusi Idumali Stumari [Sirius, a Mysterious Guest] (Tbilisi: Nakaduli, 1985) p. 105.

36 Ibid.

37 Otar Sadradze, 'Usasrulobidan' ['From Infinity], in Kosmosis Mekobreni [The Space Pirates] (Tbilisi: Nakaduli, 1986), pp. 139-179.

38 Ibid., p. 174.

39 Ibid., p. 176.

40 Shota Gagoshidze, 'Ormagi Shetsdoma' ['A Double-sided Mistake'] in Tsisperi Mnatobi Amirani [Amiran, The Blue Star] (Tbilisi: Soviet Georgia, 1979), pp. 90-102.
} 
planet. According to their experience, 'Sapiens are born only on big planets that have colossal gravitational field and they, as a rule, are giants'. ${ }^{41}$ Moreover, the aliens are sure that 'In the universe, whether in its center or in its periphery, universal laws are applicable'. ${ }^{42}$ The aliens believe that they possess the universal truth undergoes revision the second the intelligent creatures from the Earth greet them by shooting hydrogen missiles towards them. The feeling the aliens experience in front of the total 'destruction of the credibility of their beloved universal laws ${ }^{43}$ can be described as 'the shock of redefining oneself in the face of the exotic'. ${ }^{44}$ However, this shock in the story is not one-sided: the earthlings themselves have their own believe system and act accordingly. They have decided that the unidentified celestial object that had entered the solar system is a comet, because the existence of a spaceship that is 'the size of the continent of Australia' for them is unimaginable. ${ }^{45}$ This conviction changes when the object maneuvers away from the missiles and leaves the solar system.

In $A$ Double-sided Mistake the contact between two civilizations is not made; the difference between them is too big for them to find the common language without any prior preparations. But even this failed contact is enough for both of the civilizations to reevaluate their whole belief system. This is confirmed by the words uttered by an operator from the Earth, with which the story itself ends: 'Your so-called universal laws have vanished like soap-bubble with the explosion of the hydrogen missiles. From this day on, we have to evaluate the processes that occur in the universe with a completely new approach. This is the main lesson we received from the visit of our cosmic brothers. ${ }^{46}$

Jessica Langer describes postcolonial science fiction as a sub-genre that opposes western paradigms of science and progress, which deems its methodology as the only appropriate way of perceiving the reality; such a text 'questions the system itself, and explores specifically its deleterious effects on societies and cultures whose own worldviews are built on a different basis entirely' ${ }^{47}$ In $A$ Double-sided Mistake, the deleterious effects of such a system are avoided - technologically superior center willingly refuses to make the contact with indigenous people, as the contact has a potential to evolve into a conflict. This very thoughtfulness, sensitivity and humanity is the most effective instance of criticizing the colonialist aggression in the Georgian Soviet science fiction.

\footnotetext{
41 Ibid., p.91.

42 Ibid.

43 Ibid., p. 99.

${ }^{44}$ Rieder, Colonialism and the Emergence of Science Fiction, p. 67.

${ }^{45}$ Gagoshidze, 'Ormagi Shetsdoma', p. 100.

46 Ibid., p. 101.

${ }^{47}$ Langer, Postcolonialism and Science Fiction, pp. 131-132.
} 


\section{SUMMARY - THE UlTIMATE HYBRIDITY OF GEORGIAN IDENTITY}

Science fiction, the literature of technologically saturated societies, did not evolve naturally in Georgia. Sharing so many similarities with the socialist realism, it became the type of writing that was openly encouraged by the Communist Party. Thus, during some periods, mostly in the Stalinist era, writing science fiction offered the author not only a chance to secure their career, but to show loyalty towards the state and avoid a death sentence. Therefore, it is hardly surprising that the Georgian science fiction texts published between the years of 1930 and 1991 seldomly diverge from the principles set by the authoritarian state. However, the very fantastical quality of the genre that allowed the authors to more freely imagine the future left some space for national sentiments and, in a couple of cases, even for the critique of the imperialism.

The practice of mimicry does not equal the complete adoption of the center's identity; therefore, it can perfectly coexist with the national pride. When Georgia, in science fiction narratives, is represented as the center and progenitor of a communist society, or when the West is represented as its arch-enemy, the aim is not to erase the difference between the Russian and Georgian nationalities, but to appropriate the political power the Soviet Russia possessed. The fact that Russia, on the other hand, was in its own complicated Us-Them relationship with the West made the Soviet Georgian national identity even more fragmented and inconsistent. ${ }^{48}$ However, the strength of such an identity lies in its very complexity, as various opposing components can be used as a much-needed support to perform a balancing act and, thus, survive the assimilation. The absence of a monolithic identity, the displacement of a heterogeneous consciousness from a time-space continuum gives a specific uniqueness to the Soviet Georgian identity. Paradoxically, in this very instability lies the source of stability, as all of its contradictory aspects serve one unified goal - self-preservation.

\footnotetext{
${ }^{48}$ See Boris Groys, The Total Art of Stalinism (Princeton, New Jersey: Princeton University Press, 1992), Anindita Banerjee, We Modern People (Middletown, Connecticut: Wesleyan University Press, 2012), Mark Bassin, 'Russia Between Europe and Asia: The Ideological Construction of Geographical Space’ in Slavic Review (April 1991), pp. 1-17.
} 


\section{REFERENCES}

Apkhazava, Nugzar, Mzis Despani anu Uta Phasias Kosmosuri Odisea [The Emissary of the Sun or the Space Odyssey of Uta Phasia] (Tbilisi: Nakaduli,1980).

Banerjee, Anindita, We Modern People (Middletown, Connecticut: Wesleyan University Press, 2012).

Basilaia, Apolon, Chveni Misamarti [Our Home-Address] (Sablitgami, Tbilisi, 1956).

Bassin, Mark, 'Russia Between Europe and Asia: The Ideological Construction of Geographical Space’ in Slavic Review (April 1991), pp. 1-17.

Bhabha, Homi, K., The Location of Culture (Routledge, New York, 1994).

Cheishvili Tamaz, Siriusi Idumali Stumari [Sirius, a Mysterious Guest] (Tbilisi: Nakaduli,1985).

Clark, Katerina, The Soviet Novel: History as Ritual (Chicago: The University of Chicago Press, 1981).

Csicsery-Ronay, Istvan, Jr., 'Science Fiction and Empire', in Science Fiction Studies 30.2 (2003), pp. 231-245.

- The Seven Beauties of Science Fiction (Middletown, Connecticut: Wesleyan University Press, 2008).

Gagoshidze, Shota, Ormagi Shetsdoma' ['A Double-sided Mistake'] in Tsisperi Mnatobi Amirani [Amiran, The Blue Star] (Tbilisi: Soviet Georgia, 1979), pp. 90-102.

Groys, Boris, The Total Art of Stalinism: Avant-Garde, Aesthetic, Dictatorship, and Beyond (Princeton: New Jersey, Princeton University Press, 1992). 
Chartolani - Georgian Hero of the Soviet Era AgAinst the Universe: Science

FICTION AS A NATION’S COPING MECHANISM

Hirsch, Francine, Empire of Nations: Ethnographic Knowledge and the Making of the Soviet Union (Ithaca: Cornell University Press, 2005).

Kerslake, Patricia, Science Fiction and Empire (Liverpool: Liverpool University Press, 2007).

Kipiani, Ivane, 'Amoni Anu Atasi Tslis Shemdeg [Amoni or One Thousand Years After]' in Kartuli Sabchota Romani [Georgian Soviet Novel] (Tbilisi: Merani, 1987), pp. 203-399.

Langer, Jessica, Postcolonialism and Science Fiction (London: Palgrave Macmillan, 2011).

Le Guin, Ursula K., The Language of the Night (New York: Harper Perennial, 1989).

Merabishvili, Elguja, 'Tetri Usasruloba' ['The While Infinity'] in Dakarguli Andromake [Lost Andromaque] (Tbilisi: Nakaduli,1978), pp. 103-147,

- 'Aias Mdzivi' [A Bead of Aeaea'] in Dakarguli Andromake [Lost Andromaque] (Tbilisi: Nakaduli,1978), pp. 174-202.

Rieder, John, Colonialism and the Emergence of Science Fiction (Middletown, Connecticut: Wesleyan University Press, 2008).

Sadradze, Otar, 'Usasrulobidan' ['From Infinity], in Kosmosis Mekobreni [The Space Pirates] (Tbilisi: Nakaduli, 1986), pp.139-179.

Said, Edward, W., Culture and Imperialism (New York: Vintage Books, 1994)

- Orientalism (New York: Vintage Books, 1979).

Suvin, Darko, Positions and Presuppositions in Science Fiction, (Montreal: Macmillan Press, 1988).

Wells, H.G., The War of the Worlds (Rockville, Maryland: Phoenix Pick, 2008). 
Chartolani - Georgian Hero of the Soviet Era Against the Universe: Science FICTION AS A NATION'S COPING MECHANISM

Zubok, Vladislav, M., (A Failed Empire) The Soviet Union in the Cold War from Stalin To Gorvachev (Chapel Hill: The University of North Carolina Press, 2009).

This work is licensed under the Creative Commons Attribution-NonCommercial-ShareAlike 3.0 Unported License. To view a copy of this license, visit http://creativecommons.org/licenses/by-ncsa/3.0/ or send a letter to Creative Commons, PO Box 1866, Mountain View, CA 94042, USA. 